\title{
Acta
Biochimica
Polonica
}

Vol. 50 No. 1/2003

$181-190$

www.actabp.pl

\section{DNA damage and repair in lymphocytes of normal individuals and cancer patients: studies by the comet assay and micronucleus tests ${ }^{\star \Delta}$}

\author{
Olena Palyvoda ${ }^{1,3}$, Joanna Polańska ${ }^{2}$, Andrzej Wygoda ${ }^{1}$ and \\ Joanna Rzeszowska-Wolny ${ }^{1 凶}$ \\ ${ }^{1}$ Department of Experimental and Clinical Radiobiology, Center of Oncology-M. \\ Sktodowska-Curie Memorial Institute, Gliwice, Poland; ${ }^{2}$ Institute of Automatic Control, Silesian \\ University of Technology, Gliwice, Poland; ${ }^{3}$ Institute of Cell Biology, National Academy of \\ Sciences, Lviv, Ukraine
}

Received: 09 October, 2002; revised: 29 November, 2002; accepted: 17 January, 2003

Key words: human lymphocytes, DNA damage, DNA repair, comet assay, ionizing radiation, head and neck tumors

\begin{abstract}
A population study is reported in which the DNA damage induced by $\gamma$-radiation (2 Gy) and the kinetics of the subsequent repair were estimated by the comet and micronucleus assays in isolated lymphocytes of 82 healthy donors and patients with head and neck cancer before radiotherapy. The parameters of background and radiation-induced DNA damage, rate of repair, and residual non-repaired damage were measured by comet assay, and the repair kinetics for every donor were computer-fitted to an exponential curve. The level of background DNA damage before irradiation measured by comet assay as well as the level of micronuclei were significantly higher in the head and neck cancer patient group than in the healthy donors, while the parameters of repair were widely scattered in both groups. Cancer patient group contained significantly more individuals, whose irradiated lymphocytes showed high DNA damage, low repair rate and high non-repaired DNA damage level. Lymphocytes of donors belonging to this subgroup showed significantly lower inhibition of cell cycle after irradiation.
\end{abstract}

\footnotetext{
${ }^{\star}$ Preliminary report of this work was presented at the 6th International Conference SYMBIOSIS 2001, September, 2001, Szczyrk, Poland, and at the 32nd Annual Meeting of European Environmental Mutagen Society, September, 2002, Warsaw, Poland.

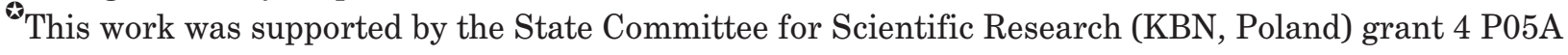
01519.

${ }^{{ }}$To whom correspondence should be addressed: Center of Oncology, 44-100 Gliwice, Poland; fax: (48 32) 231 3512; e-mail: jwolny@io.gliwice.pl
}

Abbreviations: MN, micronuclei; NDI, nuclear division index; SCCHN, squamous cell carcinoma of the head and neck. 
The exposure of cells to ionizing radiation results in induction of diverse types of DNA damage and of repair processes (Breen \& Murphy, 1995; Wojewódzka et al., 1997). The sensitivity of tumor as well as healthy tissues is crucial for successful cancer radiotherapy and depends on cell type (Maciejewski, 1997; Miyagie et al., 1997; Nascimento et al, 2001), proliferation and metabolic status (SchmidtUllrich et al., 2000) as well as on intracellular scavenger concentrations and probably many other factors (Oleinick et al., 1994; Olive et al., 1990). The tumor as well as healthy tissue response to radiotherapy may depend on the DNA repair potential of the cells. This potential is probably in high degree determined genetically and could be estimated in studies of healthy tissues (Powell \& Suit, 2000). Here we compared the differences in $\gamma$-radiation-induced DNA damage and its repair in lymphocytes of healthy donors and of patients bearing tumors, using groups larger than those previously studied (Palyvoda et $a l ., 2002)$ DNA damage was determined by the single-cell gel electrophoresis and micronucleus tests (Fairbairn et al., 1995; Fenech et al., 1993; Olive, 1999). The process of DNA repair was modeled by exponential equation and parameters of the curves describing DNA damage and repair in the patient and healthy groups were compared by statistical analyses.

\section{MATERIALS AND METHODS}

Lymphocytes and irradiation. Lymphocytes were isolated from blood of 44 healthy donors and, with informed consent, from 38 patients with squamous cell carcinoma of the head and neck (SCCHN) before conventional or accelerated radiotherapy at the Oncology Center in Gliwice (Maciejewski, 1997). The mean age in patient group was equal to 59 years (range 44-78) and in healthy donors group was equal to 40 year (range $13-78$ ). The patient group contained 34 males and 30 smokers, and healthy donors group contained 17 males and 17 smokers. Donors did not differ significantly in diet.

Peripheral blood was centrifuged in FicollHistopaque-1077 (Sigma) gradients and the lymphocytes were washed twice in phosphate-buffered saline (PBS) and cultured for $24 \mathrm{~h}$ in RPMI 1640 medium (Sigma), supplemented with $15 \%$ fetal calf serum (ICN). Lymphocytes suspended in culture medium $\left(3 \times 10^{5}\right.$ cells $\left./ \mathrm{ml}\right)$, were $\gamma$-irradiated on ice using a ${ }^{60} \mathrm{Co}$ beam at $1.14 \mathrm{~Gy} / \mathrm{min}$ to a total dose of $2 \mathrm{~Gy}$ and then incubated at $37^{\circ} \mathrm{C}$. Aliquots (100 $\mu \mathrm{l}, 3 \times 10^{4}$ cells) were taken for comet assays immediately before irradiation and at $0,15,30,60,120$ and $180 \mathrm{~min}$ after irradiation.

Comet assays. Background and radiation-induced DNA damage were assayed by the single cell electrophoresis method as described by Green (Green et al., 1992); all steps were performed on ice to prevent repair. Aliquots of lymphocytes $\left(1.5 \times 10^{4}\right.$ in $\left.50 \mu \mathrm{l}\right)$ suspended in $1 \%$ low melting agarose type VII (Sigma) were placed on microscope slides (Knittel Glasser) covered with $0.5 \%$ agarose type III (Sigma). The cells were lysed for 60 min in $2.5 \mathrm{M} \mathrm{NaCl}, 100 \mathrm{mM}$ EDTA, $10 \mathrm{mM}$ Tris/HCl, pH 7.5, 1\% Triton X-100, denaturation was for $20 \mathrm{~min}$ in $300 \mathrm{mM} \mathrm{NaOH}, 1 \mathrm{mM}$ EDTA, pH 13, and electrophoresis was in the same buffer for $20 \mathrm{~min}$ at $1 \mathrm{~V} / \mathrm{cm}$. After electrophoresis the preparations were neutralized for $5 \mathrm{~min}$ in $0.4 \mathrm{M}$ Tris $/ \mathrm{HCl}, \mathrm{pH} 7.5$, and stained with ethidium bromide. Comets were classified by fluorescence microscopy (Carl Zeiss Axiophot) into 5 categories $\left(\mathrm{A}_{0}-\mathrm{A}_{4}\right)$ according to the scale of Collins from category $\mathrm{A}_{0}$ (nucleoids without detectable damage and showing no "tail") to category $\mathrm{A}_{4}$ (totally degraded preparations in which comet heads were poorly seen and tails were highly spread). The number of comets in each category was counted in 100 objects and the mean level of DNA damage (D) was calculated by the equation $\mathrm{D}=\mathrm{A}_{1}+2 \mathrm{~A}_{2}+3 \mathrm{~A}_{3}+4 \mathrm{~A}_{4}$ (Collins et al., 1997). 
Micronucleus test. For micronucleus assays (Fenech, 1993) heparinized blood was suspended in 10 volumes of RPMI medium supplemented with $15 \%$ fetal calf serum with $100 \mathrm{u} / \mathrm{ml}$ of gentamicin (Polfa, Poland) and 5 $\mathrm{ml}$ were placed in glass Petri dishes. Immediately after irradiation with doses of 2 or 4 Gy the cells were stimulated with $5 \mu \mathrm{l} / \mathrm{ml}$ of phytohemagglutinin (Sigma) and incubated at $37^{\circ} \mathrm{C}$ in a $\mathrm{CO}_{2}$ atmosphere. After $44 \mathrm{~h}$ cytochalasin B (Sigma) was added to the medium to a final concentration of $6 \mu \mathrm{g} / \mathrm{ml}$ and incubation was continued for $72 \mathrm{~h}$. The cells were collected, fixed in Carnoy's solution, resuspended in a small volume of fixative, and dropped on onto frozen slides and air-dried. Two preparations were made per sample and the slides were coded to avoid observer bias. One day later the slides were stained with $4 \%$ Giemsa in $0.01 \mathrm{M}$ phosphate buffer, $\mathrm{pH} 6.8$, for $8 \mathrm{~min}$, and stained with May-Grunwald (POCH, Poland). The cells were observed under a light microscope (Carl Zeiss Axiophot) using a $\times 63$ planapochromatic objective. A minimum of 200 binucleate cells with well-preserved cytoplasm was scored from each slide for the presence of micronuclei (MN), identified according to the criteria of Fenech (1993). To provide data regarding proliferation kinetics, the frequencies of mono-, bi-, tri- and tetranucleate cells were determined. The nuclear division index (NDI) was calculated according to the formula NDI $=\left(1 \times \mathrm{N}_{1}\right)+\left(2 \times \mathrm{N}_{2}\right)+(4$ $\left.\times \mathrm{N}_{>2}\right) / \mathrm{n}$ (Keshava et al., 1996) where $\mathrm{N}_{1}, \mathrm{~N}_{2}$ and $\mathrm{N}_{>2}$ represent the number of lymphocytes with one, two or more than two nuclei respectively and $\mathrm{n}$ the total number of cells scored.

Statistical analyses. Statistical significance was calculated by two-sided, unpaired Student's $t$-test. Hypothesis on equality of means of independent normal random variables were verified with the use of Student's $t$-test. Testing normality of distributions was based on $\chi^{2}$, G, Smirnov-Kolmogorov, and Shapiro-Wilk statistics. In the case of deviations from normal distribution, simple com- parison between groups was done with the use of Mann-Whitney U-test and Kruskal-Wallis ANOVA rank model. The analysis was performed with the help of Matlab, Prizm 3.0 and S-PLUS software (Elston \& Johnston, 1994).

\section{RESULTS}

\section{Background DNA damage in lymphocytes}

The background level of DNA single-strand breaks in non-irradiated lymphocytes from both healthy and tumor-bearing donors was highly variable, ranging from close to zero to 300 arbitrary units $(75 \%$ of the maximum value, see Materials and Methods). In the group of patients the median background was 90.3 (lower quartile $\mathrm{q}_{25 \%} 45.3$ upper quartile $\mathrm{q}_{75 \%}$ 117.2) compared with a value of 33.3 (lower quartile $q_{25 \%} 16.1$, upper quartile $q_{75 \%}$ 59.6 ) in the group of healthy donors.

The distribution of the level of background damage in each group was assessed by calculating the percentage of the total number of individuals with background damage higher or lower than the median value for the healthy group; these subgroups were termed the "high" and "low" background damage subgroups, respectively and by definition $50 \%$ of the members of the healthy donor group were thus in the "high" subgroup. In contrast, 81.8\% (26 persons) from the patients were in the "high" background damage subgroup (Fig. 1A). The number of individuals in the "high" and "low" background damage subgroups were significantly different in the healthy and patient groups $(P=0.0126)$.

The same difference between healthy donors and patient groups was observed when the level of spontaneous micronuclei was assessed in lymphocytes: the cancer patients showed a significantly higher level of micronuclei in non-irradiated lymphocytes than healthy donors $(P=0.0034$ by the Mann-Whitney U test, Fig. 2). 
A

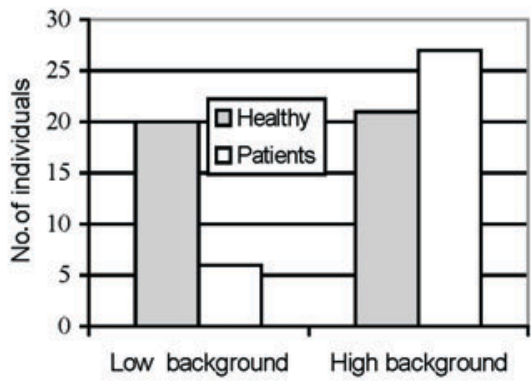

B

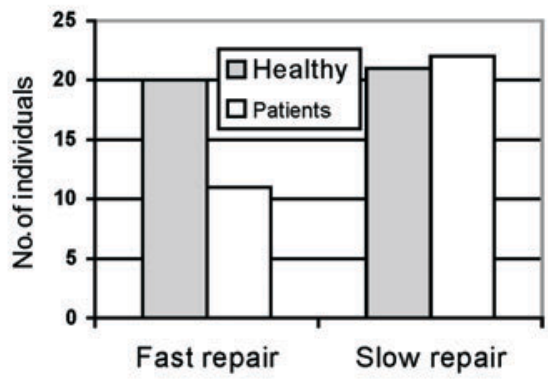

Figure 1. Numbers of healthy donors and patients with A, "low" or "high" background DNA damage or B, with "slow" or "fast" DNA repair as defined in the text.

DNA repair in lymphocytes of individual donors

Examples of the kinetics of DNA repair in lymphocytes (Fig. 3) illustrate the considerable variation between individuals, as observed previously (Palyvoda et al., 2002). For example, healthy donor \#39 showed high background DNA damage, relatively slow repair, and high non-repaired damage, patient \#6 showed even higher background damage but fast and efficient repair, and patient \#17 and healthy donor \#32 showed rather low background DNA damage but different rates and efficiency of repair.

The experimental data for different individuals, with a few exceptions discussed below, could be fitted to the exponential equation:

$$
D(t)=a \cdot e^{-\frac{t}{\tau}}+c
$$

by the numerical (Gauss-Newton) nonlinear least squares procedure, where $a$ is the radiation-induced damage at time zero, $D(t)$ the DNA damage at time $t, \tau$ the time constant inversely related to the rate of repair, and $c$ the residual non-repaired damage calculated by extrapolation (Kapiszewska et al., 1994; Wojewódzka et al., 1997; Palyvoda et al., 2002). The value of parameter $c$ returned very close to the background level of DNA damage observed before irradiation in lymphocytes of healthy donors, but in lymphocytes of tumor patients it frequently differed. The kinetics of repair for 3 healthy donors and 5 patients could not be fitted to the above equation and these data were excluded from the following statistical analyses. Repair curve obtained for patient \#20 (Fig. 3) is example of these atypical curves. Multivariate statistical analysis in which the distributions of all repair parameters were compared in healthy donor and patient groups showed significant differences between both groups (MANOVA $P=0.00686$ ). In univariate analysis in which the distributions of single parameters were compared in both groups (Mann-Whitney U test) we found a significant difference in damage induced by irradiation between patients and healthy donors.

\section{Subgroups differing in parameters of DNA repair}

The kinetics of DNA repair were compared in the subgroups whose lymphocytes showed

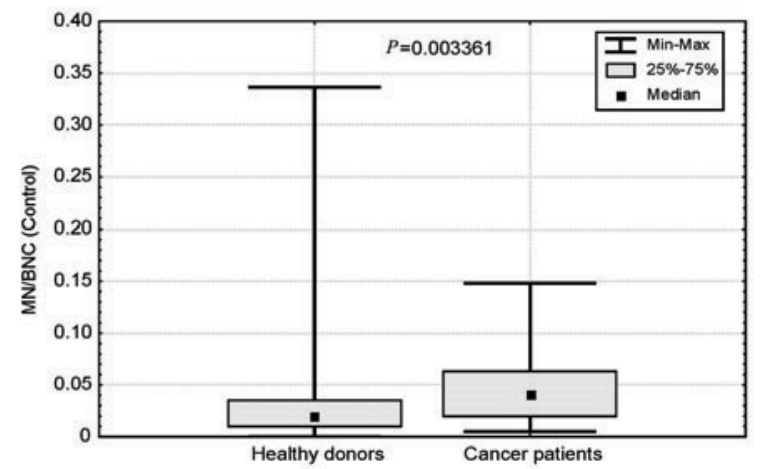

Figure 2. Frequency of spontaneous micronuclei in lymphocytes of healthy donors and cancer patients. 

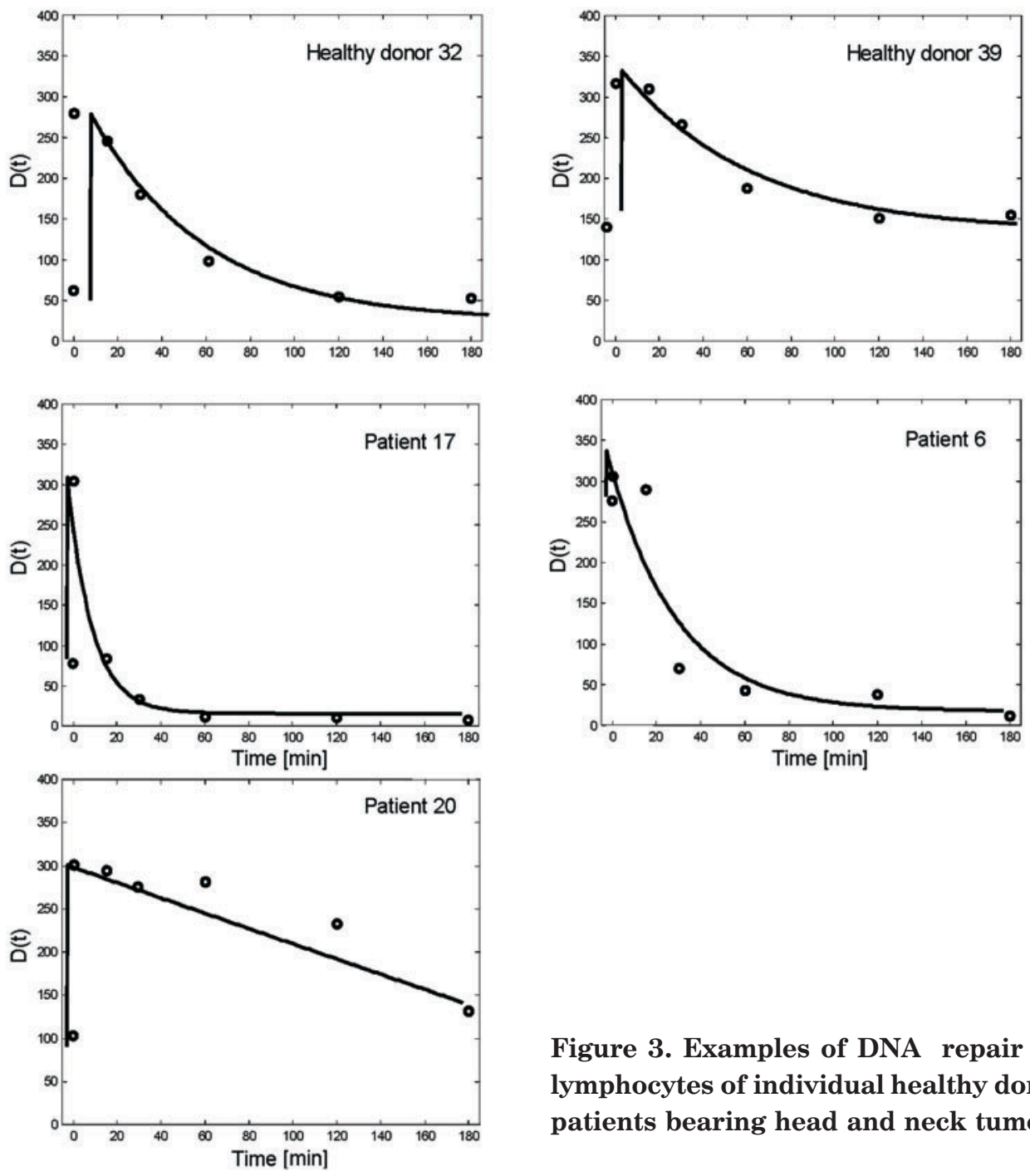

Figure 3. Examples of DNA repair kinetics in lymphocytes of individual healthy donors and of patients bearing head and neck tumors.

"high" or "low" background DNA damage (see above) using comparative statistical analysis. In patients, both subgroups showed similar median values of $\tau$ representing the rate of repair, but the median value of parameter $c$ (non-repaired DNA damage) differed significantly from that in healthy donors $(P=0.0353)$ (Table 1). In healthy donors there were no significant differences in repair kinetics between these subgroups.

The distribution of individuals with "fast" or "slow" DNA repair in each group was assessed in a similar manner as that described above for the subgroups with high or low background DNA damage. The proportion of individuals in the "fast" and "slow" repair subgroups did not differ significantly between the healthy donor and patient groups $(P=0.1807$,

Table 2), but significant differences between the groups were revealed by multivariate statistical analysis $(P=0.0450)$. The "fast" repair subgroup of healthy donors showed a significantly lower average background DNA damage than that of patients (medians 26.61 and 83.33, respectively; $P=0.0057$ ) although they presented the same level of induced and residual non-repaired damage. The "slow" repair patients had a significantly higher level of DNA damage after irradiation than the healthy donors $(P=0.0253)$ (medians 314.00 and 303.02, respectively; $P=0.0079$ ). The values and representative curves are shown in Table 2 and Fig. 4.

To search for features which could better distinguish the healthy donor and tumor patient groups, we created a subgroup termed the "all 
Table 1. Parameters of DNA repair in subgroups with low or high background DNA damage

\begin{tabular}{|c|c|c|c|c|c|c|c|c|c|c|c|c|}
\hline & \multicolumn{6}{|c|}{ Healthy donor } & \multicolumn{6}{|c|}{ Tumor patients } \\
\hline & \multicolumn{3}{|c|}{$\begin{array}{l}\text { High background } \\
\qquad 21\end{array}$} & \multicolumn{3}{|c|}{$\begin{array}{c}\text { Low background } \\
20\end{array}$} & \multicolumn{3}{|c|}{$\begin{array}{l}\text { High background } \\
\qquad 22\end{array}$} & \multicolumn{3}{|c|}{$\begin{array}{c}\text { Low background } \\
11\end{array}$} \\
\hline & $\mathrm{a}$ & $\tau$ & $\mathrm{c}$ & $\mathrm{a}$ & $\tau$ & $\mathrm{c}$ & $\mathrm{a}$ & $\tau$ & $\mathrm{c}$ & $\mathrm{a}$ & $\tau$ & $\mathrm{c}$ \\
\hline$\overline{\mathrm{x}}$ & 253.28 & 66.21 & 49.77 & 239.15 & 38.47 & 41.60 & 259.58 & 77.39 & 52.43 & 286.63 & 41.06 & 24.21 \\
\hline SEM & 21.55 & 20.97 & 37.08 & 12.12 & 7.76 & 7.47 & 19.13 & 23.68 & 19.29 & 9.56 & 5.86 & 7.16 \\
\hline Median & 255.07 & 22.37 & 32.33 & 245.09 & 28.93 & 42.64 & 240.94 & 43.04 & 71.52 & 289.45 & 41.01 & 20.96 \\
\hline
\end{tabular}

Table 2. Parameters of DNA repair in subgroups showing fast or slow repair

\begin{tabular}{|c|c|c|c|c|c|c|c|c|c|c|c|c|}
\hline & \multicolumn{6}{|c|}{ Healthy donor } & \multicolumn{6}{|c|}{ Tumor patients } \\
\hline & \multicolumn{3}{|c|}{$\begin{array}{c}\text { Slow repair } \\
21\end{array}$} & \multicolumn{3}{|c|}{$\begin{array}{c}\text { Fast repair } \\
20\end{array}$} & \multicolumn{3}{|c|}{$\begin{array}{c}\text { Slow repair } \\
27\end{array}$} & \multicolumn{3}{|c|}{$\begin{array}{c}\text { Fast repair } \\
\quad 6\end{array}$} \\
\hline & $\mathrm{a}$ & $\tau$ & $\mathrm{c}$ & $\mathrm{a}$ & $\tau$ & $\mathrm{c}$ & $\mathrm{a}$ & $\tau$ & $\mathrm{c}$ & $\mathrm{a}$ & $\tau$ & c \\
\hline $\bar{x}$ & 259.98 & 81.78 & 36.83 & 232.11 & 22.11 & 55.18 & 269.88 & 93.86 & 44.64 & 286.63 & 41.06 & 24.21 \\
\hline SEM & 20.02 & 20.58 & 20.13 & 14.19 & 1.73 & 12.41 & 22.89 & 28.13 & 23.16 & 9.56 & 5.86 & 7.16 \\
\hline Median & 260.95 & 47.35 & 32.33 & 249.13 & 23.46 & 42.56 & 244.56 & 57.06 & 60.57 & 289.45 & 41.01 & 20.96 \\
\hline
\end{tabular}

high" subgroup which was characterized by values higher than the median for background damage, induced DNA damage, parameter reflecting a slow rate of DNA repair, and residual non-repaired damage. The patient group contained a significantly higher proportion of
(Powell \& Suit, 2000; Olive, 1999) and in studies on radiation sensitivity one often has to use a population of cells that are not uniform, for example tumor cells or lymphocytes from human donors or animals. The comet assay used here has the advantage of allowing obser-

Table 3. Numbers of representatives of "All High" group in all donors, healthy donors and cancer patients groups

\begin{tabular}{lcccccc}
\hline \multirow{2}{*}{ All high } & \multicolumn{2}{c}{ All samples } & \multicolumn{2}{c}{ Cancer patients } & \multicolumn{2}{c}{ Healthy donors } \\
& $\mathrm{N}$ & $\%$ & $\mathrm{~N}$ & $\%$ & $\mathrm{~N}$ & $\%$ \\
\hline No & 58 & 78.38 & 20 & 60.61 & 38 & 92.68 \\
Yes & 16 & 21.62 & 13 & 39.39 & 3 & 7.32 \\
Total & 74 & 100 & 33 & 100 & 41 & 100 \\
\hline
\end{tabular}

individuals in this subgroup (Table 3). The lymphocytes of donors belonging to "all high" subgroup did not differ from lymphocytes of other donors in induction of micronuclei, but showed significantly lower inhibition of proliferation after $\gamma$ irradiation (Table 4 and Fig. 5).

\section{DISCUSSION}

Interaction of genotoxic agents with DNA in a population of cells is a stochastic process vation of DNA strand breaks induced by genotoxic agents or ionizing radiation in individual cells, which can be classified according to the level of DNA damage and also provide data on the entire population of cells. By analyzing comet assay results with the help of simple mathematical formula, we were able to detect significant differences between healthy donors and patients with head and neck cancer. Lymphocytes of patients differed from those of healthy donors both in their background DNA damage and in their response to 
radiation. The experimental data on the kinetics of DNA repair in irradiated lymphocytes were fitted to exponential curves whose pa-

Table 4. Comparison of subgroup „All High” (N2) with other donors (N1)

\begin{tabular}{llll}
\hline Variable & $N_{1}$ & $N_{2}$ & P value \\
\hline MN Control & 67 & 17 & .341514 \\
MN 2Gy & 67 & 17 & .573405 \\
NDI Control & 67 & 18 & .560831 \\
NDI 2Gy - Control & 67 & 18 & .003688 \\
a & $\mathbf{6 9}$ & $\mathbf{1 8}$ & .010205 \\
$\boldsymbol{\tau}$ & $\mathbf{6 9}$ & $\mathbf{1 8}$ & $\mathbf{. 0 0 0 2 7 3}$ \\
c & $\mathbf{6 9}$ & $\mathbf{1 8}$ & $\mathbf{. 0 0 0 0 0 3}$ \\
a+c & $\mathbf{6 9}$ & $\mathbf{1 8}$ & .000428 \\
Background & $\mathbf{6 9}$ & $\mathbf{1 8}$ & .000000 \\
\hline
\end{tabular}

rameters were calculated for every individual to allow quantitative comparisons. Only about $10 \%$ of donors from both the healthy and tumor patient groups could not be described by
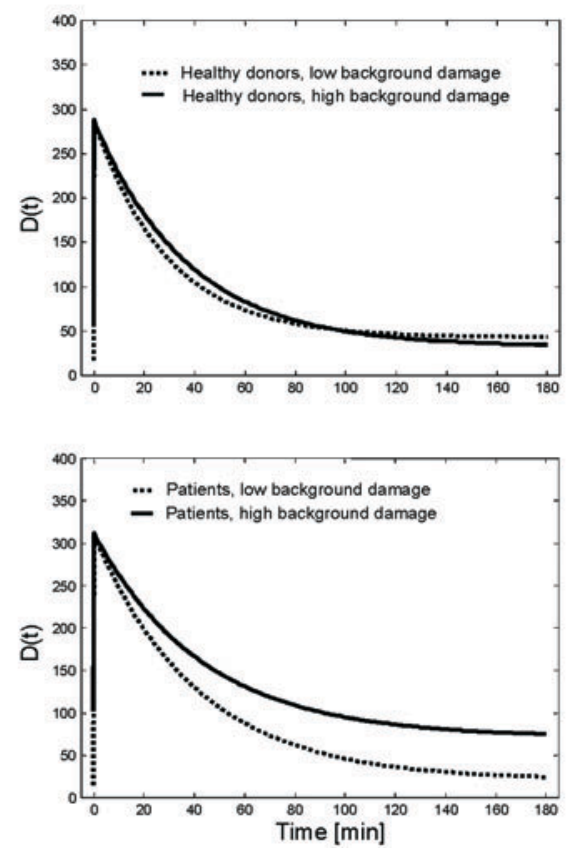

both groups as noted previously in lymphocytes and other tissues (Palyvoda et al., 2002; Miyagi et al., 1997).

Average background DNA damage in lymphocytes was significantly higher in the tumor patient group, and was higher than the healthy donors median value in a significantly greater number of members. Following irradiation, lymphocytes of tumor patients showed higher DNA damage, slower repair, and higher residual un-repaired damage than those of healthy donors. These differences could be due to variable genetic backgrounds, such as polymorphism of genes coding for repair. Sturgis and coworkers in the series of experiments showed that polymorphism and the level of expression of nucleotide excision repair genes was related to increased risk of head and neck cancers (Sturgis et al., 2000; 2002; Cheng et al., 2002). Differences in the efficiency of nucleotide excision repair could
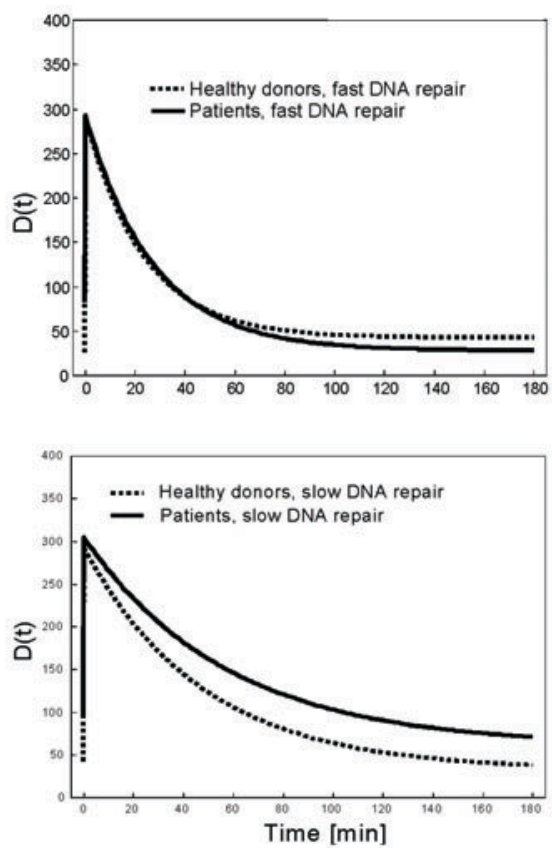

Figure 4. Median DNA repair curves in subgroups with high or low background DNA damage or with fast or slow repair.

this model, for reasons which we do not yet understand. Statistical analyses showed significant differences between the two groups, although the parameters describing the kinetics of DNA repair were broadly distributed in influence the repair of oxidative damage induced by irradiation. During repair of this type of DNA damage additional single strand breaks are generated by excision mechanisms. The appearance of such breaks may in- 
fluence the shape of DNA repair curves obtained by comet assay. The differences in DNA repair between healthy donors and patients groups could also result from differences in lymphocyte subtypes present in blood. We believe that different responses of

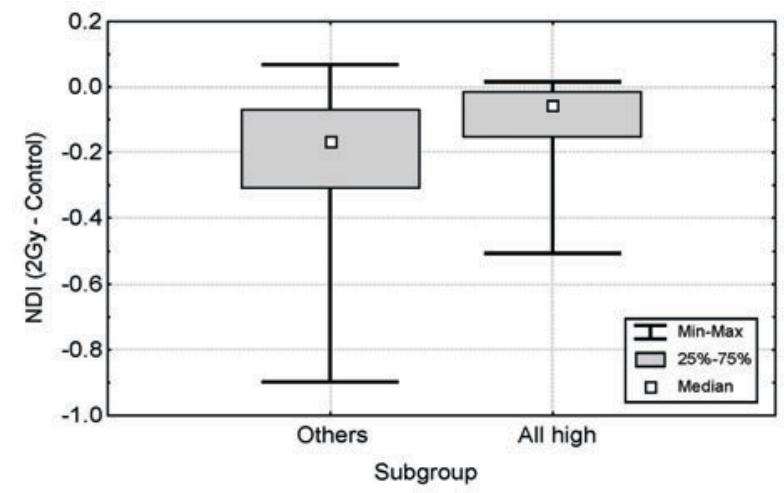

Figure 5. Differences in inhibition of lymphocyte proliferation between the subgroup "all high" (see text) and other donors.

B- and T-lymphocyte subpopulations to $\gamma$-radiation (Wuttke et al., 1993; Louagie et al., 1998) is unlikely to influence our conclusions because B lymphocytes did not exceed 5\% of the total in the preparations used here.

Healthy donors with "high" and "low" background DNA damage in lymphocytes did not differ significantly in their median repair curves, suggesting that the lower background DNA damage in this group results from factors other than a higher repair capacity. In contrast, in the patient group the median repair curves of "high" and "low" background donors were significantly different, consistent with the idea that their repair capacity is more heterogeneous possibly due to genetic polymorphism.

We are aware that two caveats remain in the interpretation of these experiments. First, the two groups compared were not matched with respect to other parameters, for reasons of the unavailability of appropriate donors. In separate series of analysis not shown in this paper we compared the distributions of repair parameters in subgroups of healthy donors differing with gender, age and smoking status. In these analysis we did not find significant differences among such subgroups. Second, the differences between healthy donors and patients could be either a cause or an effect of tumor growth; individuals with a higher background level of DNA damage and slower repair may be predisposed to developing cancer, or the characteristics of their lymphocyte population may change during the oncogenic process. Further studies are needed to answer these questions. Our results nevertheless suggest that the comet assay may be applicable to predict certain reactions of patients to radiotherapy and that further work in this direction could be fruitful.

The authors want to express gratitude to Ronald Hancock for discussion and valuable suggestions. O. Palyvoda work in Poland was supported by Polish National Commission for UNESCO and Mianowski Kasa.

\section{R E F E R E N C E S}

Brammer I, Zoller M, Dikomey E. (2001) Relationship between cellular radiosensitivity and DNA damage measured by comet assay in human normal, NBS and AT fibroblasts. Int $J$ Radiat Biol.; 77: 929-38.

Breen AP, Murphy JA. (1995) Reactions of oxyl radicals with DNA. Free Radical Biol Med.; 18: $1033-77$.

Cheng L, Sturgis EM, Eicher SA, Spitz MR, Wei Q. (2002) Expression of nucleotide excision repair genes and the risk for squamous cell carcinoma of the head and neck. Cancer.; 94: 393-7.

Collins AR, Dusinska M, Franclin M, Somorovska M, Petrovska H, Duthie S, Fillion L, Panayiotidis M, Raslova K, Vaughan N. (1997) Comet assay in human biomonitoring studies: reliability, validation and applications. Environ Mol Mutagen.; 30: $139-46$. 
Elston RC, Johnston WD. (1994) In Essentials of Biostatistics. Davis, ed., Philadelphia.

Fairbairn DW, Olive PL, O'Neill KL. (1995) The comet assay: a comprehensive review. Mutat Res.; 339: 37-59.

Fenech MF. (1993) The cytokinesis-block micronucleus technique and its application to genotoxicity studies in human populations. Environ Health Perspect.; 101: 101-7.

Green M, Low J, Harcourt SA, Akinluyi P, Row T, Cole J, Anstey AV, Arlett CV. (1992) UV-C sensitivity of unstimulated and stimulated human lymphocytes from normal and Xeroderma pigmentosum donors in the comet assay: a potential diagnostic technique. Mutat Res.; 273: 137-44.

Kapiszewska M, Szumiel I, Lange CS. (1994) Damage at two levels of DNA folding measured by fluorescent halo technique in X-irradiated L5178Y-R and L5178Y-S cells. II. Repair. Radiat Environ Biophys.; 33: 35-44.

Keshava C, Nagalakshmi R, Ong T. (1996) Inhibitory effect of folinic acid on radiation-induced micronuclei and chromosomal aberrations in V79 cells. Mutat Res.; 352: 123-34.

Louagie H, Cornelissen M, Philippe J, Vral A, Thierens H, De Ridder L. (1998) Flow cytometric scoring of apoptosis compared to electron microscopy in gamma irradiated lymphocytes. Cell Biol Int.; 22: 277-83.

Maciejewski B. (1997) Future directions for radiotherapy: gray or blue perspective? Nowotwory.; 47: 467-82.

Miyagi Y, Zhang H, Wheeler KT. (1997) Radiation-induced DNA damage in tumors and normal tissues: IV. Influence of proliferation status and cell type on the formation of oxygen-dependent DNA damage in cultured cells. Radiat Res.; 148: 29-34.

Nascimento PA, da Silva MA, Oliviera EM, Suzuki M, Okazaki K. (2001) Evaluation of radioinduced damage and repair capacity in blood lymphocytes of breast cancer patients. Brazilian J Med Biol Res.; 34: 165-76.

Oleinick N, Balasubramaniam U, Xue L, Chiu S. (1994) Nuclear structure and the microdistribution of radiation damage in DNA. Int J Radiat Biol.; 66: 523-9.

Olive PL. (1992) DNA organization affects cellular radiosensitivity and detection of initial DNA strand breaks. Int J Radiat Biol.; 62: 389-96.

Olive PL. (1999) DNA damage and repair in individual cells: applications of the comet assay in radiobiology. Int $J$ Radiat Biol.; 75: 395-405.

Olive PL., Banath JP, Durand RE. (1990) Detection of etoposide resistance by measuring DNA damage in individual Chinese hamster cells. J Natl Cancer Inst.; 82: 779-83.

Palyvoda O, Mukalov I, Polanska J, Wygoda A, Drobot L, Widel M, Rzeszowska-Wolny J. (2002) Radiation-induced DNA damage and its repair in lymphocytes of patients with head and neck cancer and healthy donors. Anticancer Res.; 22: 1721-6.

Powell S, Suit HD. (2000) Radiation biology for radiation oncologist. In Clinical radiation oncology: indications, techniques and results. Wang CC., ed, pp 46-8. Wiley-Liss Inc.

Schmidt-Ullrich RK, Dent P, Grant S, Mikkelsen RB, Valerie K. (2000) Signal transduction and cellular radiation responses. Radiat Res.; 153: $245-57$.

Sokal RR, Rohlf FJ. (1997) Biometry. The principles and practice of statistics in biological research. 3rd edn. W.H. Freeman and Co. New York.

Sturgis EM, Zheng R, Li L, Castillo EJ, Eiher SA, Chen M, Strom SS, Spitz MR, Wei Q. (2000) XPD/ERCC2 polymorphisms and risk of head and neck cancer: a case-control analysis. Carcinogenesis.; 21: 2219-23.

Sturgis EM, Castillo EJ, Eiher SA, Strom SS, Spitz MR, Wei Q. (2002) XPD/ERCC2 exon 8 polymorphisms: rarity and luck of significance in risk of squamous cell carcinoma of the head and neck. Oral Oncol.; 38: 475-7.

Sturgis EM, Dahlstrom KR, Spitz MR, Wei Q. (2002) DNA repair gene ERCC1 and ERCC2/XPD polymorphisms and risk of squamous cell carcinoma of the head and 
neck. Arch Otolaryngol Head Neck Surg.; 128: 1084-8.

Terris DJ, Ho EY, Ibrahim HZ, Dorie MJ, Kovacs MS, Le QT, Koong AC, Pinto HA, Brown JM. (2002) Estimating DNA repair by sequential evaluation of head and neck tumor radiation sensitivity using the comet assay. Arch Otolaryngol Head Neck Surg.; 128: 698-702.

Wojewódzka M, Kruszewski M, Szumiel I. (1997) Effect of signal transduction inhibition in adapted lymphocytes: micronuclei frequency and DNA repair. Int $J$ Radiat Biol.; 71: 245-52.

Wuttke K, Streffer C, Muller W. (1993) Radiation induced micronuclei in subpopulations of human lymphocytes. Mutat Res.; 286: 181-8.

Wygoda A, Skladowski K. (1999) Risk factors for the toxicity of radiation treatment of head and neck cancer. Nowotwory.; 49: 7-13. 